\title{
A Recognized Value System among Nurses Working in Poland
}

\author{
Beata Bajurna1, Anna Galęba², Jerzy T. Marcinkowski ${ }^{3}$ \\ ${ }^{1}$ Chair and Department of Organization and Management in Health Care, Poznan University of Medical \\ Sciences, Poznan, Poland \\ ${ }^{2}$ Private Practice of Aesthetic Medicine and Anti-Aging in Warszawa and Poznan, Poland \\ ${ }^{3}$ Chair of Social Medicine, Department of Hygiene, Poznan University of Medical Sciences, Poznan, Poland \\ Email: jtmarcin@gmail.com
}

Received 30 December 2014; accepted 16 January 2015; published 26 January 2015

Copyright (C) 2015 by authors and Scientific Research Publishing Inc.

This work is licensed under the Creative Commons Attribution International License (CC BY). http://creativecommons.org/licenses/by/4.0/

(c) (i) Open Access

\begin{abstract}
Aim of this work was to present a study indicating the recognized system of values of nursing units in healthcare entities in Poland. Professionally active nurses (249) employed in medicinal entities were subjects in the study. A random selection of individuals was applied in the study, and the participation in the research was declared by respondents consent to participate in it. A survey was used as the main form of measurement, and it was divided into direct and indirect survey. A standardized Rokeach's scale of values [1] [2] consisting of two collections, each of which included 18 single values, was used. They were ranked by tested individuals according to the hierarchy of their values which allowed for recognizing which are the most important for them. Kruskal-Wallis's test was applied in the study. Results: The social position is the most important value for nurses working in the district medical entities. For those working in the regional medical units, the most appreciated value is being ambitious, whereas in the clinical self-esteem. The socio-demographic data such as age, length of service, levels of education differentiate assessments of each recognized values in the group of nurses. The women between 31 and 40 consider being ambitious as the most important value, between 41 and 50 responsibility and between 20 and 30 self-esteem; responsibility is the most appreciated value for people with 21 - 25 years of experience because the older and more experienced the nurse is, the stronger her sense of responsibility becomes. A social position was appreciated the most by the nurses holding a nursing degree. Conclusions: There have been significant differences in terms of accepted values between nurses working in the district, provincial and clinical medical entities. Socio-demographic data such as age, length of service, education levels differentiate assessment of each recognized value in the group of nurses.
\end{abstract}




\section{Keywords}

\section{Value System, Nurses, Healthcare Entity}

\section{Introduction}

Nurses are part of the healthcare's human resources. Their professional training to provide healthcare services influences the quality of treatment and prevention. A nurse is a person prepared to perform actions resulting from her profession, including, first and foremost, nurturing, because it is an essential part of her profession. In addition, she organizes nursing care at all levels of the healthcare system and cooperates with a therapeutic team in health, human life, family and society protection [3].

Descriptions characterizing nurses are changing, revealing transformations taking place in the consciousness of nurses themselves, their rights and qualification based competences, in the minds of the representatives of the medical and paramedical professions, with whom nurses cooperate as well as society, who is offered the nursing care [4].

Analyzing professional functioning of nurses, M. D. Głowacka stated that their professional activities include both instrumental tasks, as well as expressive ones. The first of them requires from an employee expertise and practical skills, while the second requires pro-social behaviors. However, she pointed out that both the scope and the way of fulfilling these tasks are inter alia dependent on emotional reaction of nurses, preferred system of values, as well as external factors [5].

Due to the fact that people are subjects of nurses' actions, it becomes important for them to recognize the hierarchy of values and measures for their implementation. The term "value" is ambiguous and beyond the colloquial language; it also occurs in many scientific disciplines. As M. Kłosiński and Z. Lubowicz recognize, this concept may occur interchangeably with the words: need, attitude, drive or life objectives [6]. It may seem that the evaluation process is completely subjective and depends only on the individual that makes a decision. However, this is not so simple. M. Lesicki suggests that consideration should be given to the social functioning of the human being. He claims that both the self-imitation and conformism, as well as coercion should be treated very seriously and their impact on the process of "subjective" imitation ought to be appreciated [7].

Many psychologists working with an issue of values claim that they are closely related to issues of personality. They use personality to determine human's relationships with the environment, and also to give us the image of activities and motivation in connection with adopted and implemented comprehensive concept of one own life [8].

Assuming that people appreciate different values, superiors, prior to hiring the candidate for the job, could use the evaluation scales for suitability of the person for the job. The compliance of the cherished values by the employee with the organization, typically affects the productivity and job satisfaction. However, everyone is led out in life by an individual system of values. They are recognized, and then to a certain extent appreciated and preferred. Therefore, the values become one of the most important factors in motivating human behavior. They designate man's course of action by setting specific life goals and stimulate dynamic behavior by channeling energy for action. It also occurs in a society of professional nurses. The values adopted for implementation, are being shaped, fixed and modified throughout one's life, as a result of the expansion of knowledge, experience and social stimulation. The values and goals adopted for implementation are disseminated, strengthen and represent examples for other members of the population. And they can then be evaluated by potential customers (patients) as factors affecting the work done by nurses [9].

Man is a creature that develops his own individual path. According to M. Grzywak-Kaczynska, a man at birth does not know anything, and only during the course of life one learns, experiences things, and appreciates life emotionally. People are faced with a variety of situations and then choose the best option for oneself and one's environment [10].

Speaking of the profession of nurse one cannot forget the fundamental principles of coexisting, another man and his needs also cannot be ignored. Nurses are entrusted with the health and life of humans. This profession has characteristics of calling, for it comes from the relish to care for people. It is difficult to require a lot of human's 
perseverance and dedication. Formerly, maintaining ethical standards meant nurses' obedience to doctors and loyalty towards the hospital. Nowadays it is the loyalty towards the values, taking ethical norms into account [11].

\section{Materials and Methods}

Professional nurses (249 people), employed in medicinal entities with different degrees of references were subjects of the study. In the tested population there were nurses employed in clinical and regional medical entities$39.4 \%$ (98 nurses) and 37.8\% (94 nurses) respectively. The lowest number of tested nurses were employed in a district medical entities-22.9\% (57 people). There were relatively large differences in age between nurses. 20 30 year old nurses accounted for the highest number of examined population (42.6\%), and the 41 - 50 year old ones were the smallest group (22.9\%). Women with 11 - 15 years of professional experience dominated and accounted for $46 \%$ of the tested population. The smallest part accounted for nurses with a work experience between 16 - 30 years; 4.4\%. The largest number of the tested women held a secondary education-47.8\%. It should also be noted that 112 nurses (45\%) had Bachelor's degree in nursing, and the lowest number accounted for the ones who had a higher degree in nursing (7.2 percent).

Random selection of individuals was used, and the condition for participation was a declared written agreement of respondents. Primary poll measurements were used as a main form of testing, and among that group of measurements direct and indirect pools were implemented. Rokeach's standardized scale of values was also used in the study [1]. It is an adaptation of the American test called Rokeach Value Survey (RVS) version E. The adaptive work was carried out by P. Brzozowski in 1978-1982. It consists of two collections, each of which included 18 single values. The first group contains definitive values relating to the desired final purposes of existence, while the second are instrumental values referring to the preferred ways of behavior or measures to achieve the ultimate values. Ranked by the poll participants according to the hierarchy of their importance allowed to find out which are the most important for them.

For the analysis of the empirical material, computer program Statistica 6.0 was used. Statistical tests were conducted at the severity level of $\alpha=0.05$. Kruskal-Wallis test-nonparametric equivalent of the analysis of variance, used in cases when the F-test cannot be counted (nonequivalent groups or tested variable that follow different from normal distribution) was used.

\section{Results}

Based on Rokeach's standardized scale of values, nurses' system of value was examined. According to M. Rokeach value is a stable belief that a particular way of behavior or the final state of existence is personally or socially preferable to the alternative way of behavior or the final state of existence ordered according to the relative importance [1]. The task of the surveyed person was to order individual values according to their importance (1) from the most to the least important (18).

Taking into account the 18 definite values, it was found that the results of the Kruskal-Wallis test point to the significant differences in the statistics presented below.

In Table 1, there are all relevant results of the Kruskal-Wallistests (significance $p<0.05$ ), that is the ultimate values, for which there was a significant distinction between examined nurses, depending on the type of entity.

- The result for the variable "ambitious" is significant $(\mathrm{H}=28.60 ; \mathrm{p}=0.00)$, so the nurses depending on the healthcare entity differ in assessing this variable. The highest rating was given by nurses in the provincial entity $(M=6.33)$ and lowest in clinical $(M=2.63)$.

- The result for the variable "ability" is significant $(\mathrm{H}=96.61 ; \mathrm{p}=0.00)$, so the nurses depending on the healthcare entity differ in assessing this variable. The highest rating was given by nurses in the district entity $(\mathrm{M}=10.23)$ and lowest in clinical $(\mathrm{M}=2.87)$.

- The result for the variable "clarity" is significant $(\mathrm{H}=118.42 ; \mathrm{p}=0.00)$, so the nurses depending on the healthcare entity differ in assessing this variable. The highest rating was given by nurses in the provincial entity $(M=12.71)$ and lowest in district $M=2.96)$.

- The result for the variable "tolerance" is significant $(H=124.14 ; p=0.00)$, so the nurses depending on the healthcare entity differ in assessing this variable. The highest rating was given by nurses in the provincial entity $(M=12.48)$ and lowest in district $(M=3.05)$. 
Table 1. The results of the Kruskal-Wallis test for ultimate values system and the type of healtcare entity $(N=249)$.

\begin{tabular}{|c|c|c|c|c|}
\hline $\begin{array}{l}\text { Variable } \\
\text { Ambitious }\end{array}$ & $\mathrm{N}$ important & Mean M & Average range & Kruskal-Wallis test \\
\hline District & 57 & 5.89 & 134.28 & \\
\hline Provincial & 94 & 6.33 & 149.39 & $\begin{aligned} H & =28.60 \\
p & =0.00\end{aligned}$ \\
\hline Clinical & 98 & 2.63 & 96.21 & \\
\hline $\begin{array}{l}\text { Variable } \\
\text { Ability }\end{array}$ & $\mathrm{N}$ important & Mean M & Average range & Kruskal-Wallis test \\
\hline District & 57 & 10.23 & 182.42 & \\
\hline Provincial & 94 & 7.36 & 144.95 & $\begin{array}{c}H=96.61 \\
p=0.00\end{array}$ \\
\hline Clinical & 98 & 2.87 & 72.47 & \\
\hline $\begin{array}{l}\text { Variable } \\
\text { Clarity }\end{array}$ & $\mathrm{N}$ important & Mean M & Average range & Kruskal-Wallis test \\
\hline District & 57 & 2.96 & 35.08 & \\
\hline Provincial & 94 & 12.71 & 160.32 & $\begin{array}{c}H=118.42 \\
\mathrm{p}=0.00\end{array}$ \\
\hline Clinical & 98 & 11.63 & 143.42 & \\
\hline $\begin{array}{l}\text { Variable } \\
\text { Tolerance }\end{array}$ & $\mathrm{N}$ important & Mean M & Average range & Kruskal-Wallis test \\
\hline District & 57 & 3.05 & 34.51 & \\
\hline Provincial & 94 & 12.48 & 165.78 & $\begin{array}{c}H=124.14 \\
\mathrm{p}=0.00\end{array}$ \\
\hline Clinical & 98 & 10.57 & 138.52 & \\
\hline $\begin{array}{l}\text { Variable } \\
\text { Helpfulness }\end{array}$ & $\mathrm{N}$ important & Mean M & Average range & Kruskal-Wallis test \\
\hline District & 57 & 11.49 & 170.95 & \\
\hline Provincial & 94 & 2.97 & 51.80 & $\begin{array}{c}H=157.09 \\
p=0.00\end{array}$ \\
\hline Clinical & 98 & 11.23 & 168.49 & \\
\hline $\begin{array}{l}\text { Variable } \\
\text { Imaginative }\end{array}$ & $\mathrm{N}$ important & Mean M & Average range & Kruskal-Wallis test \\
\hline District & 57 & 10.84 & 124.79 & \\
\hline Provincial & 94 & 11.90 & 140.84 & $\begin{array}{l}H=8.87 \\
p=0.01\end{array}$ \\
\hline Clinical & 98 & 9.78 & 109.93 & \\
\hline $\begin{array}{l}\text { Variable } \\
\text { Obedience }\end{array}$ & $\mathrm{N}$ important & Mean M & Average range & Kruskal-Wallis test \\
\hline District & 57 & 12.72 & 167.82 & \\
\hline Provincial & 94 & 3.60 & 54.70 & $\begin{array}{c}H=144.86 \\
p=0.00\end{array}$ \\
\hline Clinical & 98 & 12.72 & 167.53 & \\
\hline
\end{tabular}


- The result for the variable "helpfulness" is significant $(\mathrm{H}=157.09 ; \mathrm{p}=0.00)$, so the nurses depending on the healthcare entity differ in assessing this variable. The highest rating was given by nurses in the district entity $(\mathrm{M}=11.49)$ and lowest in provincial $(\mathrm{M}=2.97)$.

- The result for the variable "imaginative" is significant $(\mathrm{H}=8.87 ; \mathrm{p}=0.01)$, so the nurses depending on the healthcare entity differ in assessing this variable. The highest rating was given by nurses in the provincial entity $(M=11.90)$ and lowest in clinical $(M=9.78)$.

- The result for the variable "obedient" is significant $(H=144.86 ; p=0.00)$, so the nurses depending on the healthcare entity differ in assessing this variable. The highest rating was given by nurses in the district and clinical entity $(\mathrm{M}=12.72)$ and lowest in provincial $(\mathrm{M}=3.60)$.

Kruskal-Wallis test also indicated the statistically significant differences among the instrumental values (Table 2).

- The result for the variable "comfortable life" is significant $(H=88.12 ; p=0.00)$, so the nurses depending on the healthcare entity differ in assessing this variable. The highest rating was given by nurses in the provincial entity $(M=11.01)$ and lowest in district $(M=2.28)$.

- The result for the variable "safety of the family" is significant $(\mathrm{H}=7.22 ; \mathrm{p}=0.02)$, so the nurses depending on the healthcare entity differ in assessing this variable. The highest rating was given by nurses in the district entity $(M=8.44)$ and lowest in provincial $(M=6.28)$.

- The result for the variable "freedom" is significant $(\mathrm{H}=86.74 ; \mathrm{p}=0.00)$, so the nurses depending on the healthcare entity differ in assessing this variable. The highest rating was given by nurses in the district entity $(\mathrm{M}=9.11)$ and lowest in clinical $(\mathrm{M}=3.20)$.

- The result for the variable "happiness" is significant $(\mathrm{H}=70.32 ; \mathrm{p}=0.00)$, so the nurses depending on the healthcare entity differ in assessing this variable. The highest rating was given by nurses in the clinical entity $(\mathrm{M}=8.73)$ and lowest in district $(\mathrm{M}=2.91)$.

- The result for the variable "self-dignity" is significant $(H=76.85 ; \mathrm{p}=0.00)$, so the nurses depending on the healthcare entity differ in assessing this variable. The highest rating was given by nurses in the clinical entity $(\mathrm{M}=8.09)$ and lowest in provincial $(\mathrm{M}=3.11)$.

- The result for the variable "social position" is significant $(\mathrm{H}=76.44 ; \mathrm{p}=0.00)$, so the nurses depending on the healthcare entity differ in assessing this variable. The highest rating was given by nurses in the district entity $(M=9.95)$ and lowest in provincial $(M=3.14)$.

- The result for the variable "wisdom" is significant $(\mathrm{H}=11.35$; $\mathrm{p}=0.00)$, so the nurses depending on the healthcare entity differ in assessing this variable. The highest rating was given by nurses in the provincial entity $(\mathrm{M}=10.48)$ and lowest in district $(\mathrm{M}=8.20)$.

- The result for the variable "real friendship" is significant $(H=7.32 ; \mathrm{p}=0.02)$, so the nurses depending on the healthcare entity differ in assessing this variable. The highest rating was given by nurses in the provincial entity $(M=8.84)$ and lowest in district $(M=7.18)$.

In addition, it was examined whether demographic factors such as age, professional experience, education, position, type of entity, influence nurses' value choice.

In this study the values such as responsibility, ambitious, social position, self-esteem and skills (five the most cherished values) were evaluated. The results of the Kruskal-Wallis's test (Table 3) indicate that the values recognized by the nurses are differentiated by demographic factors. In the case of age criterion-The statistically important differences were observed in such values as ambition $(p=0.014)$, responsibility $(p=0.013)$, selfesteem ( $p=0.001)$. As a result of the research, it was also noted that the demographic factor "age" varies the assessment of the above values. And so, a group 31 to 40 years old most appreciates the ambition, while people aged 41 to 50 responsibility. Self-esteem was found the most popular among nurses aged 20 - 30 years.

Another demographic factor analyzed in the study was the professional experience. In this case, the result of the test is statistically significant in the case of responsibility values ( $p=$ value of 0.012 ). Similarly in the case of age, there appeared clear differences according to age. A responsibility was the most valued for people aged 21 - 25.

Significant differences can be also seen also by analyzing the level of education. The test turned out to be statistically significant only for social position values $(p=0.045)$. It was the highest rated by the nurses with a nursing degree.

An analysis of the relationship between the recognized values and the type of the medical entity was conducted. In this case, the test results showed that nurses working in a variety of different entities differently appreciate such values as: ambitions $(p=0.000)$, skills $(p=0.000)$, self-esteem $(p=0.000)$ and social position $(p=$ 
Table 2. The results of the Kruskal-Wallis test for instrumental value system and the type of healtcare entity $(N=249)$.

\begin{tabular}{|c|c|c|c|c|}
\hline $\begin{array}{c}\text { Variable } \\
\text { Comfortable life }\end{array}$ & N important & Mean M & Average range & Kruskal-Wallis test \\
\hline District & 57 & 2.28 & 46.89 & \multirow{3}{*}{$\begin{array}{c}H=88.12 \\
p=0.00\end{array}$} \\
\hline Provincial & 94 & 11.01 & 152.23 & \\
\hline Clinical & 98 & 10.49 & 144.31 & \\
\hline $\begin{array}{c}\text { Variable } \\
\text { Safety of the family }\end{array}$ & $\mathrm{N}$ important & Mean M & Average range & Kruskal-Wallis test \\
\hline District & 57 & 8.44 & 147.07 & \multirow{3}{*}{$\begin{array}{l}H=7.22 \\
p=0.02\end{array}$} \\
\hline Provincial & 94 & 6.28 & 116.29 & \\
\hline Clinical & 98 & 6.59 & 120.52 & \\
\hline $\begin{array}{l}\text { Variable } \\
\text { Freedom }\end{array}$ & $\mathrm{N}$ important & Mean M & Average range & Kruskal-Wallis test \\
\hline District & 57 & 9.11 & 166.75 & \multirow{3}{*}{$\begin{aligned} H & =86.74 \\
p & =0.00\end{aligned}$} \\
\hline Provincial & 94 & 8.40 & 154.13 & \\
\hline Clinical & 98 & 3.20 & 72.78 & \\
\hline $\begin{array}{l}\text { Variable } \\
\text { Happiness }\end{array}$ & $\mathrm{N}$ important & Mean M & Average range & Kruskal-Wallis test \\
\hline District & 57 & 2.91 & 55.14 & \multirow{3}{*}{$\begin{aligned} H & =70.32 \\
p & =0.00\end{aligned}$} \\
\hline Provincial & 94 & 8.68 & 142.48 & \\
\hline Clinical & 98 & 8.73 & 148.86 & \\
\hline $\begin{array}{l}\text { Variable } \\
\text { Self-dignity }\end{array}$ & $\mathrm{N}$ important & Mean M & Average range & Kruskal-Wallis test \\
\hline District & 57 & 7.42 & 151.93 & \multirow{3}{*}{$\begin{aligned} H & =76.85 \\
p & =0.00\end{aligned}$} \\
\hline Provincial & 94 & 3.11 & 73.96 & \\
\hline Clinical & 98 & 8.09 & 158.30 & \\
\hline $\begin{array}{c}\text { Variable } \\
\text { Social position }\end{array}$ & N important & Mean M & Average range & Kruskal-Wallis test \\
\hline District & 57 & 9.95 & 196.70 & \multirow{3}{*}{$\begin{aligned} H & =76.44 \\
p & =0.00\end{aligned}$} \\
\hline Provincial & 94 & 3.14 & 98.35 & \\
\hline Clinical & 98 & 3.36 & 108.86 & \\
\hline $\begin{array}{c}\text { Variable } \\
\text { Real friendship }\end{array}$ & $\mathrm{N}$ important & Mean M & Average range & Kruskal-Wallis test \\
\hline District & 57 & 8.12 & 98.39 & \multirow{3}{*}{$\begin{aligned} H & =11.35 \\
p & =0.00\end{aligned}$} \\
\hline Provincial & 94 & 10.48 & 138.67 & \\
\hline Clinical & 98 & 9.67 & 127.37 & \\
\hline $\begin{array}{l}\text { Variable } \\
\text { Wisdom }\end{array}$ & N important & Mean M & Average range & Kruskal-Wallis test \\
\hline District & 57 & 7.18 & 111.76 & \multirow{3}{*}{$\begin{array}{l}H=7.32 \\
p=0.02\end{array}$} \\
\hline Provincial & 94 & 8.84 & 140.53 & \\
\hline Clinical & 98 & 7.36 & 117.80 & \\
\hline
\end{tabular}


Table 3. Results of the Kruskal-Wallis’s test—evaluation of individual values/demographic factors.

\begin{tabular}{|c|c|c|c|c|c|c|}
\hline $\begin{array}{l}\text { Values and demographic } \\
\text { factors }\end{array}$ & Responsibility & Ambitions & Social position & Self-esteem & Skils & Kruskal-Wallis's test \\
\hline \multirow{4}{*}{ Age } & 8.762 & 8.543 & 2.390 & 13.492 & 5.337 & $\mathrm{H}$ \\
\hline & 2 & 2 & 2 & 2 & 2 & Degrees of freedom \\
\hline & 0.013 & 0.014 & 0.303 & 0.001 & 0.069 & importance \\
\hline & 14.720 & 4.290 & 5.979 & 7.848 & 6.071 & $\mathrm{H}$ \\
\hline \multirow[t]{3}{*}{ Professional experience } & 5 & 5 & 5 & 5 & 5 & Degrees of freedom \\
\hline & 0.012 & 0.508 & 0.308 & 0.165 & 0.299 & importance \\
\hline & 2.070 & 3.011 & 6.194 & 5.962 & 7.461 & $\mathrm{H}$ \\
\hline \multirow[t]{3}{*}{ Level of education } & 2 & 2 & 2 & 2 & 2 & Degrees of freedom \\
\hline & 0.355 & 0.222 & 0.045 & 0.051 & 0.024 & importance \\
\hline & 2.115 & 28.600 & 76.448 & 76.857 & 96.610 & $\mathrm{H}$ \\
\hline \multirow[t]{2}{*}{$\begin{array}{l}\text { The type of the } \\
\text { medical entity }\end{array}$} & 2 & 2 & 2 & 2 & 2 & Degrees of freedom \\
\hline & 0.347 & 0.000 & 0.000 & 0.000 & 0.000 & importance \\
\hline
\end{tabular}

0.000). The social position was the most valued by nurses from district medical entities, they also highly valued abilities. In the provincial medical entities nurses highly appreciated being ambitious while in the clinical entities self-esteem.

\section{Discussion}

Conducted research of nurses' and midwives' opinions on the necessary values needed to practice their profession [12] and presented at the International Scientific Conference Nursing towards endangerment of values100th anniversary of the birth of Hanna Chrzanowska (Cracow, Poland 11-12.10.2002), showed the relationship between shaping the values by the medical school and their use at work. It has been confirmed that not everyone can be a nurse. Making decision about the choice of profession one was guided by the values associated with an attitude towards another human being, willingness of helping him and calling (75\%). However, for the most important values the following were considered: responsibility, knowledge, patience, caregiving, skills, conscientiousness and integrity that is values in accordance with the characteristics of the created model of nursing personality.

Each nurse has her own hierarchy of values shaped by education, culture, religion and life experience, and so by demographic factors. They influence the assessment of the quality of nursing care both at the unit and at the whole entity. Professional values are clearly specified in the "code of nursing ethics" [13]. This document formally sets the standards for the group of professionals. For example, "code for nurses" reflects the professional values, noting that the inherent from the nursing is respect for life, dignity and human rights. While the preamble of "code for nurses" of American Nursing Association states that the code of ethics expresses (...) the basic values of the profession. In the "code of nursing ethics" of the Canadian Nursing Association each value is analyzed separately and is supplemented by the description of the related duties of the nurse. "Code of ethics" of the New Zealand Nursing Association enumerates the values in relation to the patient, a group of colleagues, the social dimension of professional practice and professional association. Codes of ethics make the values of professional nursing available to the public and indicate the most important ones that should be included in the training programs [14].

Several studies have been carried out, which confirmed that the scale of values of M. Rokeach, varies according to the group. However, it was also noted that persons belonging to the same category or occupational group usually share similar values [15]. M. Rokeach believed that values are beliefs that become information to the 
person concerned about a particular object. These values, according to him, are a permanent conviction as to how to behave or exist, as well as they are both personally and socially accepted [16]. M. Rokeach divided the system of values into two main groups-the ultimate values and instrumental.

Choosing by the interviewees one list, as this, which reflects their lifestyle, provides an opportunity to assess the hierarchy of values and preferred objectives and ways of achieving them. The hierarchy of instrumental values is a result of the intra-psychic order of the criteria for evaluation of the process of achieving life goals. This assessment includes, therefore, the target, and its compliance in the implementation of the standards owned by the person. Making a correlation between the obtained materials in this regard and the results on the effectiveness of the professional test group, allows for establishing a link between the hierarchy of values and effective implementation of professional roles regarding patients, staff, the institution, by the nurse [17].

In this work there has been presented system of values of nurses employed in different types of healthcare entities and differences in the values considered as ultimate and instrumental have been pointed out. Based on IBM and IRIC research, it has been noted that system of values varies at a national level, rather than organizational [18]. The results, which have been obtained in this work, allow noting, that these differences were observed at the level of organization with the same profile. They indicate that nurses working in a variety of entities differently appreciate such ultimate values as: ambition, ability, tolerance, helpfulness, imaginative, obedience and differently appreciate the instrumental values, like; comfortable life, safety of the family, freedom, happiness, self-dignity, social position, true friendship, wisdom. In this study there were selected five most cherished values. Statistically significant results have shown that in district healthcare entity the most important for nurses is the social position, but also they appreciate the ability as value. In the provincial medicinal entity the value of ambition is the most cherished, while in the clinical healthcare entity self-dignity. In the analysis of the tests carried out by Hofstede and IRIC attention was paid to the additional criteria-demographic factors-which could affect test results [18].

The working group of nurses has started to create a new image. The scope of actions has changed, as new areas of nursing knowledge have opened up. The socio-professional role of nurses has also changed. By fulfilling their professional functions in conscious, knowledgeable and responsible way nurses take creative efforts to develop nursing professional ethics. This involves a desire to identify and clarify the nature of nurture and extend autonomy and accountability. In the era of great progress and social and political changes the world of values is imbalanced. Some people in the pursuit of materialistic goods forget about the basic principles of cohabitation, and do not notice another man and his needs.

Presented bedside behaviors not always are the evidence of dignity of nurse's profession. It sometimes happens that they evidently deviate from generally accepted professional correctness, breaking the rules included in the records of the professional "Code of nursing ethics," as well as violate human dignity. Therefore, it is concluded that it is necessary to return to the basics (values). There is a need to promote a code of professional ethics, which, within the meaning of legislative validity is positioned the lowest, however, within the rank of the dignity of the profession it is a priority [19].

Nurses form their own professional group and social position generated on the basis of common values and goals. These objectives are created for implementation of professional practice and the knowledge of nurturing. Patterns and value of the nurses also apply for the group and determine its behavior. At the time of application of such knowledge, nurses will work more effectively in the healthcare system.

\section{Conclusions}

Based on the statistical analysis of the collected research material and the results of the research, the following conclusions have been formed:

1) Significant differences were observed in terms of accepted values among nurses working in different entities.

2) In the ultimate values, there was an important distinction among examined nurses, depending on the type of healthcare entity in the following variables: ambition, ability, tolerance, helpfulness, imaginative, obedience.

3) In the instrumental values, there was an important distinction among examined nurses, depending on the type of healthcare entity in the following variables: comfortable life, safety of the family, freedom, happiness, self-dignity, social position, true friendship, wisdom.

4) In a district medical entities, social position is the most valued by nurses, in the regional most appreciated 
value is being ambitious, and in clinical-self-esteem.

5) Socio-demographic data such as age, length of service, education levels differentiate assessment of each recognized value in the group of nurses.

6) A group of 31 to 40 years old nurses appreciated being ambitious the most, while the women aged 41 to 50 responsibility. Self-esteem was found the most popular among nurses aged 20 - 30 years.

7) Responsibility is the most valued by nurses with 21 - 25 years of professional experience.

8) A social position was appreciated the most by the nurses holding a nursing degree.

\section{References}

[1] Brzozowski, P. (1993) Polska wersja testu wartości Rokeach'a i jej teoretyczne podstawy. Przegląd Pedagogiczny, No. 2.

[2] Robbins, S.P. (2001) Zasady zachowania w organizacji. Wyd. Zysk i S-ka, Poznań.

[3] McNulty, B., Raiman, J., Chapman, V., Clark, J.M., Kirkham, S. and Hill, D. (1989) Pielęgniarstwo. In: Collins, S. and Parker, E., Eds., Propedeutyka pielegniarstwa, Wyd. Lekarskie PZWL, Warszawa, 21-25.

[4] Zahradniczek, K. and Zobro, M. (2002) Funkcje zawodowe i standardy pracy pielęgniarek. Magazyn Pielęgniarki i Położnej, No. 2.

[5] Głowacka, M.D. (1989) Niektóre osobowościowe i sytuacyjne wyznaczniki efektywności zawodowej pielęgniarki. Pielęgniarstwo Polskie, No. 1.

[6] Kłosiński, M. and Lubowicz, Z. (1985) Uwagi o problematyce i metodzie badań. Raportkońcowy, IBPM, Warszawa.

[7] Lesicki, M. (2014) Pojęcie i koncepcje wartości. http://www.awans.oswiata.org.pl/

[8] Ostrowska, K. (2004) W poszukiwaniu wartości. Rubikon, Kraków.

[9] Bajurna, B. (2011) Czynniki determinujące efektywność kierowania zespołem pielęgniarskim w zakładach opieki zdrowotnej. Praca Doktorska, Uniwersytet Medyczny im, Karola Marcinkowskiego, Poznań.

[10] Grzywak-Kaczyńska, M. (1988) Trud rozwoju. Instytut Wydawniczy PAX, Warszawa.

[11] Jakubiec, J. (2001) Etos pielęgniarek a etyka zawodowa. Problemy pielęgniarstwa, Zarząd Główny PTP, Warszawa.

[12] Krzemień, G., Naworska, B. and Wąc, K. (2002) Etos zawodu pielęgniarki i położnej. In: Pielęgniarstwo wobec zagrożenia wartości-100-lecie urodzin Hanny Chrzanowskiej, Materiały konferencyjne, Wyd. Fall, Kraków.

[13] Kodeks etyki zawodowej dla pielęgniarki i położnej Rzeczypospolitej Polskiej. Przyjęty Uchwałą nr 9 Krajowego Zjazdu Pielęgniarek i Położnych w dniu 9 grudnia 2003 roku.

[14] Dobrowolska, B. (2002) Kodeksy etyki zawodowej pielęgniarek. In: Wrońska, I. and Mariański, J., Eds., Etyka w pracy pielegniarskiej, Wyd. Czelej, Lublin, 203-239.

[15] Robbins, S.P. (2001) Zasady zachowania w organizacji. Wyd. Zysk i S-ka, Poznań.

[16] Brzozowski, P. (1989) Opracowanie skali wartości Schelera. Wyd. Uniwersytetu M. Curie-Skłodowskiej, Lublin.

[17] Głowacka, M.D. (1996) Model kształcenia kadr pielęgniarskich w zakresie zarządzania. Wyd. Uczelniane Akademii Medycznej, Poznań.

[18] Hofstede, G. (2000) Kultury i organizacje. Zaprogramowanie umysłu, PWE, Warszawa.

[19] Janus, B. (2005) Dylematy etyczne w pracy pielęgniarki-Model podejmowania decyzji, referat na konferencję Kompetencje pielęgniarek i położnych a odpowiedzialność moralno-zawodowa, zorganizowaną przez OIPiP, Poznań. 
Scientific Research Publishing (SCIRP) is one of the largest Open Access journal publishers. It is currently publishing more than 200 open access, online, peer-reviewed journals covering a wide range of academic disciplines. SCIRP serves the worldwide academic communities and contributes to the progress and application of science with its publication.

Other selected journals from SCIRP are listed as below. Submit your manuscript to us via either submit@scirp.org or Online Submission Portal.
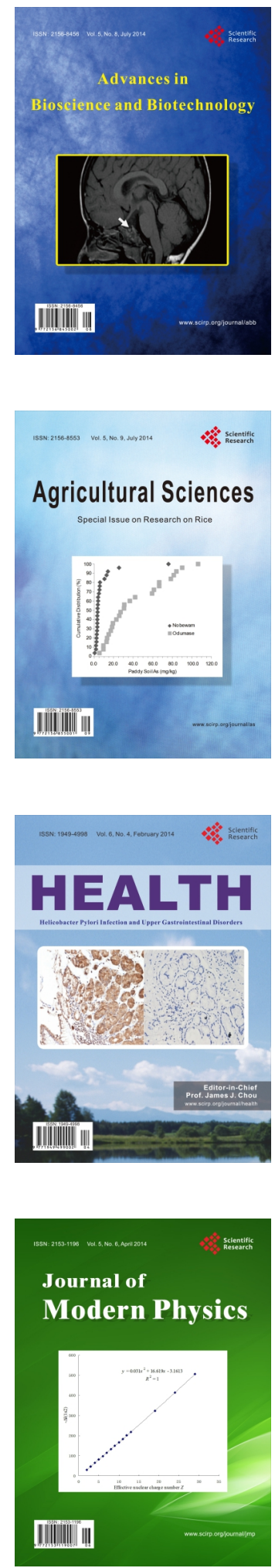
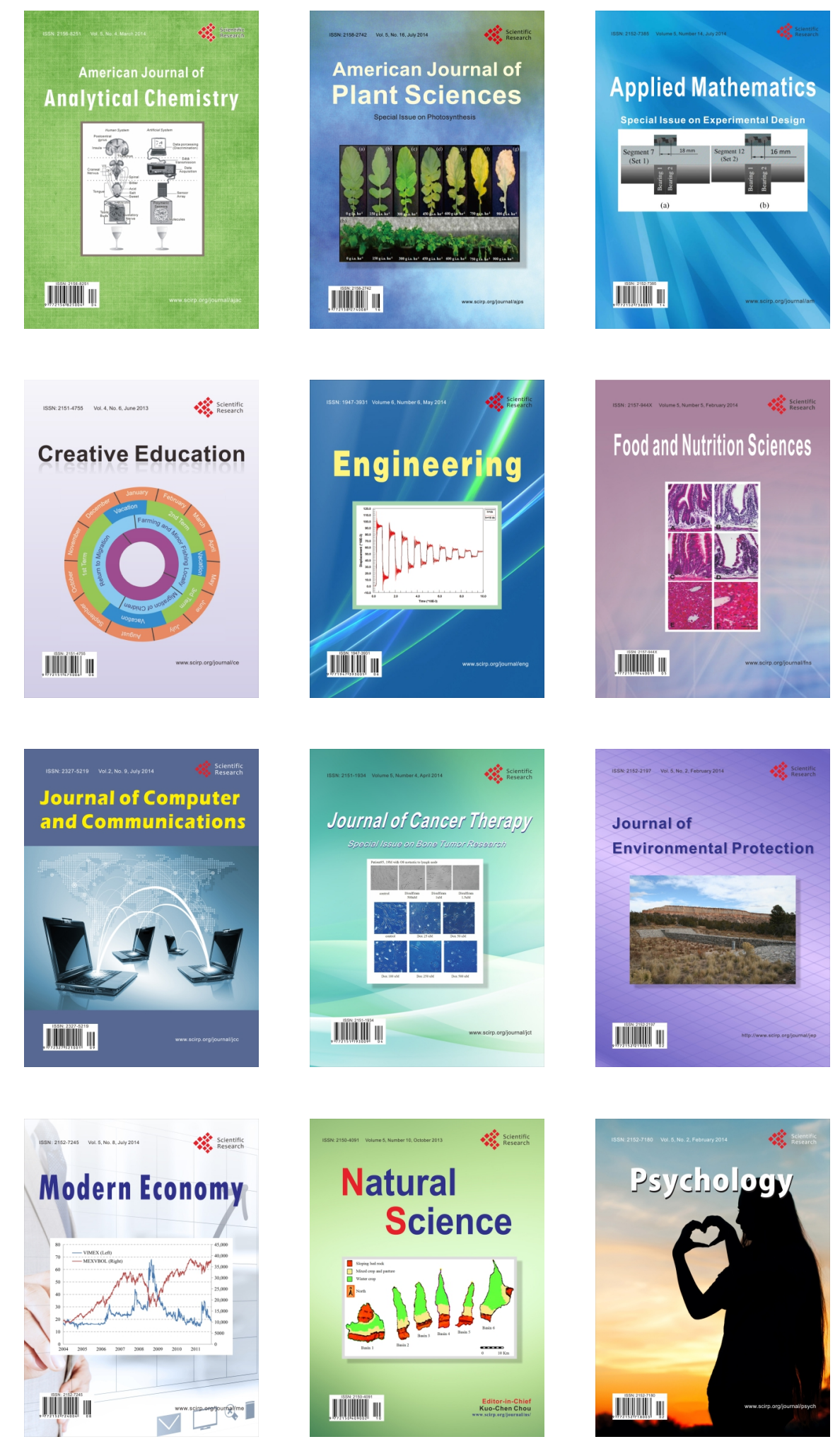